\title{
Wprowadzenie do problematyki ewolucji immunitetów mających swoje źródło w prawie międzynarodowym
}

Problematyka immunitetów mających swoje źródło w prawie międzynarodowym jest jednym z najszerzej dyskutowanych zagadnień w doktrynie zarówno prawa międzynarodowego, jak i poszczególnych dziedzin prawa krajowego, w ramach których immunitety te są realizowane ${ }^{1}$. Niniejsza publikacja poświęcona jest zachodzącym obecnie zmianom, jakim poddawane są różne postaci immunitetów (w szczególności immunitet państwa, funkcjonariuszy państwa, immunitety dyplomatyczne oraz immunitet organizacji międzynarodowych). Założeniem autorów jest udzielenie odpowiedzi na ogólne, ale niezwykle ważne pytanie: w jakim stopniu i zakresie immunitety muszą pozostać niewzruszalne w interesie

${ }^{1}$ Należy wskazać przede wszystkim: H. Lauterpacht, The Problem of Jurisdictional Immunities of Foreign States, BYIL 1951, vol. 28; X. Yang, State Immunity in International Law, Cambridge 2012; J. Bröhmer, State Immunity and the Violation of Human Rights, Haga 1997; H. Fox, The Law of the State Immunity, Oxford 2008; J. W. Dellapenna, Foreign State Immunity in Europe, 5 N.Y. INT'L L. REV. 51, 61 (1992); A. Wyrozumska, Polskie sady wobec immunitetu państwa obcego, PiP 2000, z. 3; Ch. Tomuschat, The International Law of State Immunity and Its Development by National Institutions, „Vanderbilt Journal of Transnational Law” 2011, vol. 44; S. Knuchel, State Immunity and the Promise of Jus Cogens, „Northwestern Journal of International Human Rights” 2011, vol. 9; A. Orakhelashvili, State Immunity and Hierarchy of Norms: Why the House of Lords Got It Wrong, EJIL 2008, vol. 18, no. 5; L. M. Caplan, State Immunity, Human Rights, and Jus Cogens: A Critique of the Normative Hierarchy Theory, AJIL 2003, vol. 97; I. Wuerth, International Law in Domestic Courts and the Jurisdictional Immunities of the State Case, „Melbourne Journal of International Law" 2012, vol. 13; M. Wasiński, Immunitet państwa a jurysdykcja terytorialna (na tle orzeczenia SN w sprawie Natoniewski v. RFN), PiP 2012, z. 10; A. Wyrozumska, Zajęcie i egzekucja z konta bankowego ambasady, PiP 2012, z. 10; P. Grzegorczyk, Immunitet państwa w postepowaniu cywilnym, Warszawa 2010. 
utrzymania porządku międzynarodowego i zapewnienia sprawnego funkcjonowania państwa lub organizacji międzynarodowej w stosunkach międzynarodowych, $\mathrm{w}$ jakim zaś powinny być ograniczone, np. w interesie ochrony jednostki, w tym ochrony jej praw podstawowych.

Najwięcej kontrowersji i problemów praktycznych budzi obecnie immunitet państwa. Jest on koncepcją prawa międzynarodowego wywodzącą się z zasady par in parem non habet imperium, zgodnie z którą państwo, bez swojej zgody, nie może podlegać jurysdykcji innego państwa. Obecnie nie ulega wątpliwości, że immunitet państwa znajduje podstawę prawną nie tylko w ogólnych zasadach prawa międzynarodowego, ale przede wszystkim w normach zwyczajowych tego prawa. Rozwój stosunków międzynarodowych i coraz dalej idąca aktywność państw w sferach tradycyjnie regulowanych prawem prywatnym spowodowały, że koncepcja absolutnego immunitetu została wyparta przez teorię ograniczonego immunitetu państwa. Zgodnie z tą ostatnią państwo korzysta $\mathrm{z}$ immunitetu w zakresie działań władczych (iure imperii), ale nie w zakresie działań prywatnoprawnych (iure gestionis). Od lat 70. XX w. teoria ograniczonego immunitetu znalazła swój wyraz zarówno w aktach prawa międzynarodowego, jak i krajowego. Mimo stosunkowo powszechnej praktyki potwierdzającej istnienie normy zwyczajowej, stanowiącej podstawę odmowy uznania immunitetu w odniesieniu do działań de iure gestionis, zakres tej normy nadal budzi szereg wątpliwości. W szczególności są one widoczne w praktyce sądów krajowych, która wykazuje istotne rozbieżności $\mathrm{w}$ interpretacji pojęcia czynności de iure imperii i de iure gestionis. W niektórych przypadkach szeroka interpretacja działań prywatnoprawnych państwa prowadzi do wyłączenia immunitetu w odniesieniu do działań, które dotychczas traktowane były jako wykonywanie władztwa publicznego ${ }^{2}$.

Obok wyjątku opartego na prywatnoprawnym charakterze czynności w XX w. pojawiła się koncepcja wyłączenia immunitetu w zakresie odpowiedzialności deliktowej państwa za czyny popełnione w całości lub części na terytorium państwa forum, na którym sprawca szkody był obecny (tzw. tort exception) ${ }^{3}$. Zgodnie z wyjaśnieniami Komisji Prawa Międzynarodowego wyłączenie immunitetu w takiej sytuacji stanowi wyjątek od ogólnej zasady immunitetu państwa w zakresie odpowiedzialności deliktowej i odpowiedzialności cywilnej wynikającej z działań lub zaniechań, które spowodowały uszkodzenie ciała osoby fizycznej lub szkodę w jej własności. Immunitet jurysdykcyjny w sprawach cywilnych ma swoje źródło i przyczynę w zapewnieniu stabilności prawa międzynarodowego

${ }^{2}$ Zob. M. Kałduński, Immunitet państwa. Nowe tendencje $i$ wyzwania, s. 9 i nast.

${ }_{3}$ Znajduje to potwierdzenie w art. 11 Konwencji Bazylejskiej, który wyłącza powołanie się przez pozwane państwo na immunitet jurysdykcyjny w sprawach o zadośćuczynienie za uszkodzenie ciała lub naprawienie szkody wyrządzonej w mieniu, jeżeli uszkodzenie to lub szkoda wynikły wskutek zdarzeń, które miały miejsce na terytorium państwa sądu orzekającego, a sprawca był obecny na tym terytorium, kiedy doszło do tych zdarzeń. Podobne rozwiązania przewidziano w art. 12 konwencji Narodów Zjednoczonych o immunitecie państwa. 
i ochronie dobrych stosunków między państwami. Oznacza to, że pojawiający się wyjątek powinien być interpretowany wąsko. Będzie on miał zastosowanie wyłącznie w odniesieniu do szkód materialnych. Działanie lub zaniechanie będące przyczyną szkody musi mieć miejsce w całości lub części na terytorium państwa forum, a sprawca musi być tam obecny. Charakter aktu stanowiącego przyczynę szkody (de iure imperium, de iure gestionis) pozostaje przy tym bez znaczenia. Tort exception będzie miał zatem zastosowanie m.in. do działań sił zbrojnych państwa na terytorium innego państwa. Prawem właściwym dla określenia istnienia i zakresu odpowiedzialności jest lex delicti commissi. Uzasadnieniem dla ograniczenia immunitetu państwa w opisanych sytuacjach jest konieczność zapewnienia jednostkom środków ochrony prawnej i dostępu do wymiaru sprawiedliwości w sytuacji doznania szkody na osobie lub szkody materialnej. Nadal jednak wątpliwe pozostaje zastosowanie tort exception do szkód powstałych wskutek konfliktu zbrojnego 4 .

Również rozwój prawa międzynarodowego, w szczególności zmiana statusu jednostki, w tym wzmocnienie międzynarodowej ochrony praw człowieka, oraz coraz szersza akceptacja norm peremptoryjnych (ius cogens) w prawie międzynarodowym są uznawane za czynniki ograniczające możliwość powoływania się przez państwo na immunitet. Zgodnie z art. 53 Konwencji wiedeńskiej o prawie traktatów z 1969 r. normą peremptoryjną jest taka norma powszechnego prawa międzynarodowego, która została przyjęta i uznana przez międzynarodową społeczność państw jako całość za normę, od której żadne odstępstwo nie jest dozwolone i która może być zmieniona jedynie przez późniejszą normę postępowania prawa międzynarodowego o tym samym charakterze. Katalog norm uznanych powszechnie za ius cogens pozostaje nadal wąski i obejmuje zakaz agresji, ludobójstwa, niewolnictwa, dyskryminacji rasowej, zbrodni przeciwko ludzkości i tortur oraz prawo do samostanowienia ${ }^{5}$. Są to materialne reguły postępowania, które zakazują zachowań niemożliwych do zaakceptowania ze względu na zagrożenie,

${ }^{4}$ A. Gattini, To What Extent are State Immunity and Non-Justiciability Major Hurdles to Individuals' Claims for War Damage, JlICJ 2003, vol. 1; idem, War Crimes and State Immunity in the Ferrini Decision, JIICJ 2005, vol. 3; M. Panezi, Sovereign Immunity and Violations of Jus Cogens Norms, Revue hellenique de droit international 56 (2003), s. 200; E. Castorina, E. Raffiotta, Jurisdictional Immunity of a Sovereign State in Italy: FRG vs. Italian Republic; P. Franzina, State Immunity in Respect of Serious Violations of Human Rights: the Case Law of the Italian Supreme Court in the Eve of its Appraisal by the ICJ, [w:] W. Czapliński, B. Łukańko, Problemy prawne w stosunkach polsko-niemieckich u progu XXI wieku, Warszawa 2009, odpowiednio s.112 i 118; P. Da Sena, F. Da Vittor, State Immunity and Human Rights: the Italian Supreme Court Decision in the Ferrini case, EJIL 16 (2005), s. 89; A. Ciampi, The Italian Court of Casssation Asserts Civil Jurisdiction over Germany in a Criminal Case Relating to the Second World War, The Civitella Case, JlICJ 7 (2009), s. 597.

${ }_{5}$ Draft Articles on Responsibility of States for Internationally Wrongful Acts, with commentaries (2001), United Nations 2008, s. 112; A. Wyrozumska, Zajęcie i egzekucja z konta bankowego ambasady (w niniejszym tomie). 
jakie stwarzają dla państw, ich narodów oraz podstawowych wartości człowie$\mathrm{ka}^{6}$. Naruszenie tych norm powoduje bezprawność i w konsekwencji nielegalność sytuacji powstałych w skutek naruszenia. Trudno jednak na podstawie praktyki i opinii doktryny uznać, że naruszenie międzynarodowych norm ius cogens może samo w sobie pozbawiać państwo immunitetu. Oznaczałoby to bowiem znaczne rozszerzenie zakresu skutku norm ius cogens ${ }^{7}$. Jako normy prawa materialnego nie określają one i nie determinują reguł proceduralnych dochodzenia roszczeń na płaszczyźnie prawa krajowego. Tymczasem immunitet państwa jest normą proceduralną uniemożliwiającą prowadzenie postępowania przeciwko państwu8. Choć jego źródło stanowi zasada suwerennej równości państw, pozostaje on środkiem proceduralnym mającym na celu zapewnienie jej ochrony9.

Immunitet państwa, podobnie jak inne immunitety mające swoje źródło w prawie międzynarodowym, coraz częściej jest konfrontowany z prawami człowieka $^{10}$, w szczególności z prawem do sądu. Jako norma blokująca postępowa-

${ }^{6}$ Ibidem, s. 85.

${ }^{7}$ Zob. art. 53 Konwencji Wiedeńskiej o prawie traktatów z 1960 r. Zob. też m.in orzeczenia: Międzynarodowego Trybunału Karnego d.s. byłej Jugosławii z dnia 10 grudnia 1998 r. w sprawie IT-95-17/1-T, Prosecutor v. Furundzija, ILM, vol. 38, no. 2 (March 1999), s. 317, i Brytyjskiej Izby Lordów w sprawie Regina v. Bow Street Metropolitan Stipendiary Magistrate and Others, ex parte Pinochet Ugarte (No. 3), ILR, vol. 119.

${ }^{8}$ Odmiennie: Ch. Swinarski, Kadr normatywny immunitetu jurysdykcyjnego państwa w prawie międzynarodowym (w kontekście Europejskiej Konwencji Praw Człowieka), (w niniejszym tomie) który uznaje immunitet państwa za normę materialną.

${ }^{9}$ Por. orzeczenie Sądu Najwyższego z dnia 29 października 2010 r., w sprawie Winicjusza Natoniewskiego, sygn. akt CSK 465/09, w którym Sąd, dowołując się do poglądów doktryny, stwierdził, że „nie może być mowy o sprzeczności między normami przyznającymi państwu immunitet a normami iuris cogentis, ponieważ chodzi o dwa różne rodzaje norm. Pierwsze mają charakter procesowy, a drugie materialnoprawny, dlatego nie można wywodzić z normy zakazującej tortur nakazu uchylenia immunitetu państwa w sprawach o zadośćuczynienie za tortury, podobnie jak nie można z normy statuującej immunitet wyprowadzić sensownie normy zezwalającej na stosowanie tortur. Materialna norma prawa międzynarodowego publicznego, nie gwarantując możliwości jej sankcjonowania przed zagranicznym sądem krajowym, nie może tym samym kolidować z normą dotyczącą immunitetu państwa, która to sankcjonowanie uniemożliwia. Odrębność, z jednej strony, materialnych gwarancji w dziedzinie praw człowieka, a z drugiej, procesowego obowiązku udzielenia ochrony w sferze tych praw, daje się uzasadnić założeniami prawa międzynarodowego publicznego, respektującymi suwerenność poszczególnych państw. Immunitet państwa, choć stoi na przeszkodzie zbadaniu legalności postępowania państwa przed sądami zagranicznymi, nie wyklucza załatwienia sporu z udziałem państwa metodami typowymi dla prawa międzynarodowego publicznego". Zob. też powołane w wyroku orzecznictwo ETPC i sądów krajowych oraz wyrok MTS z dnia 14 lutego 2002 r. w sprawie Kongo przeciwko Belgii. W wyroku tym Międzynarodowy Trybunał Sprawiedliwości potwierdził oparty na prawie zwyczajowym immunitet osób sprawujących najwyższe funkcje państwowe i nie dopatrzył się na obecnym etapie rozwoju tego prawa wyjątku od wskazanego immunitetu.

${ }^{10} \mathrm{Ch}$. Swinarski, Kadr normatywny immunitetu jurysdykcyjnego państwa w prawie międzynarodowym...; M. Balcerzak, Immunitety w orzecznictwie Europejskiego Trybunału Praw Człowieka, s. 67 i nast. 
nie przeciwko innemu państwu, niewątpliwie ogranicza on prawo gwarantowane w art. 6 EKPC. Europejski Trybunał Praw Człowieka, rozstrzygając sprawy, w których kwestionowana jest zgodność stosowania norm o immunitecie z Konwencją, odwołuje się do obowiązujących w tym zakresie norm zwyczajowych powszechnego prawa międzynarodowego, a jego stanowisko uwzględnia funkcję immunitetu $\mathrm{w}$ prawie międzynarodowym ${ }^{11}$. Jednocześnie praktyka Trybunału potwierdza rozwój norm zwyczajowych ograniczających immunitet państwa, zwłaszcza w stosunkach zatrudnienia w placówkach konsularnych i dyplomatycznych państw ${ }^{12}$. Ograniczenia te jednak nie wynikają wprost z Konwencji, ale ze zwyczajowego prawa międzynarodowego, a państwa strony Konwencji są zobowiązane je stosować, aby zapewnić poszanowanie praw gwarantowanych Konwencją. Postulaty relatywizacji immunitetu i przyjęcia jego autonomicznego znaczenia na gruncie ETPC nie znajdują odzwierciedlenia w praktyce orzeczniczej Trybunału. Immunitet państwa jako instytucja powszechnego prawa międzynarodowego może pełnić swoją funkcję jedynie, jeśli właśnie w ten sposób określony jest jego charakter normatywny. Nadanie mu autonomicznego charakteru na gruncie wyodrębnionego reżimu traktatowego podważałoby samą istotę prawa i porządku międzynarodowego. Europejski Trybunał Praw Człowieka wydaje się właściwie postrzegać swoją rolę nie tylko jako sądu praw człowieka, ale również międzynarodowego trybunału rozstrzygającego o zobowiązaniach państw, w niektórych przypadkach również wynikających z powszechnego prawa międzynarodowego, w zgodzie z tym prawem.

Immunitet państwa opiera się na normach zwyczajowych powszechnego prawa międzynarodowego, które częściowo znalazły swój wyraz w Konwencji ONZ o immunitecie państwa i jego własności z 2004 r. Konwencja ta, powstała m.in. w wyniku prac Komisji Prawa Międzynarodowego, stanowi w znacznej mierze kodyfikację obowiązującego prawa międzynarodowego, a w pewnym zakresie stanowi element kształtowania się nowych norm. Choć nie weszła ona jeszcze w życie, jak zauważają Autorzy, jest ona powoływana przez sądy jako wyraz prawa zwyczajowego.

Zwyczajowy charakter norm regulujących immunitet państwa powoduje, że szczególne znaczenie przy rozstrzyganiu istnienia i zakresu immunitetu państwa w konkretnych sprawach ma dialog sędziowski z innymi sądami, w tym sądami międzynarodowymi. Uwzględnianie praktyki sądów innych jurysdykcji, zarówno afirmatywne, jak i krytyczne, ma istotne znaczenie dla rozwoju prawa o immunitecie państwa. Postulat kierowany przez Autorów niniejszej publikacji do sędziów krajowych podkreśla ich rolę jako nie tylko organów stosujących prawo międzynarodowe, ale również je współkształtujących.

${ }^{11}$ Zob. I. C. Kamiński, Immunitet jurysdykcyjny państwa między klasycznym prawem międzynarodowym a prawem praw czlowieka - uwagi na kanwie wyroku Al-Adsani przeciwko Wielkiej Brytanii (w niniejszym tomie).

12 Zob. M. Balcerzk, op. cit., I. C. Kamiński, op. cit. 
W praktyce występuje szereg problemów dotyczących rozróżnienia poszczególnych rodzajów immunitetów, zwłaszcza immunitetu państwa i immunitetów dyplomatycznych. W praktyce polskiej, mimo że teoretycznie immunitety te w oczywisty sposób różnią się co do przedmiotu i zakresu, sądy mają niekiedy trudności w dokonaniu rozróżnienia w konkretnej sprawie. Szczególnie problematyczne sprawy dotyczą przedstawicieli dyplomatycznych lub pomieszczeń misji dyplomatycznych (placówek konsularnych), ich majątku, zatrudnienia w placówkach dyplomatycznych i konsularnych. Misje dyplomatyczne, placówki konsularne i inne misje nie korzystają z odrębnej od państwa wysyłającego osobowości prawnej. Było to podkreślane w orzecznictwie polskim i innych państw europejskich $\mathrm{w}$ sprawach wnoszonych przeciwko przedstawicielom dyplomatycznym, ambasadom, konsulatom itp. W konsekwencji czasami uznawano, że pozwanym jest $\mathrm{w}$ istocie państwo lub też odrzucano pozew, często błędnie przyjmując, że zastosowanie mają immunitety dyplomatyczne ${ }^{13}$. Mimo kodyfikacji prawa zwyczajowego dokonanej w art. 11 Konwencji o immunitecie państwa i jego własności, kwestie dotyczące stosunków zatrudnienia nadal stanowią problematyczny obszar dla praktyki krajowej ${ }^{14}$.

Rozwój prawa międzynarodowego i stosunków międzynarodowych prowadzi do rozszerzania zakresu podmiotowego immunitetów. Obok immunitetów przysługujących państwu i jego funkcjonariuszom coraz istotniejszy staje się problem immunitetów organizacji międzynarodowych ${ }^{15}$. Inaczej niż w przypadku państw, trudno znaleźć $\mathrm{w}$ prawie międzynarodowym materialną podstawę (analogiczną do zasady suwerennej równości państw) do uznania immunitetu organizacji międzynarodowych za immamentną normę powszechnego prawa międzynarodowego. Wytworzenie się norm powszechnego prawa międzynarodowego w tej dziedzinie również napotyka trudności wynikające m.in. z funkcjonalnego charakteru organizacji międzynarodowych, którego konsekwencją jest niejednorodność kategorii organizacji międzynarodowych. Problematyczny jest również zakres immunitetu i dopuszczalne wyjątki - czy immunitet organizacji powinien mieć charakter absolutny, czy dopuszczalne są wyjątki, a jeśli tak, to czy ich zakres powinien być analogiczny do przesłanek wyłączenia immunitetu państwa, czy też powinien odzwierciedlać specyfikę tych podmiotów prawa międzynarodowego i obejmować jedynie działania związane z realizacją funkcji i celów danej organizacji międzynarodowej.

Jednym z rozwiązań problemów związanych ze stosowaniem w praktyce immunitetu jest przyjęcie ustawy krajowej, tak jak to ma miejsce na przykład w Sta-

${ }^{13}$ A. Wyrozumska, Rozróżnienie immunitetu państwa oraz immunitetów dyplomatycznych, s. 44 i nast.

${ }_{14}$ P. Grzebyk, Zatrudnianie pracowników w placówkach państw obcych na terenie Polski - zagadnienie immunitetu jurysdykcyjnego w sprawach cywilnych (w niniejszym tomie).

$15 \mathrm{~J}$. Menkes, Immunitet jurysdykcyjny organizacji międzynarodowej-immunitet jurysdykcyjny państwa: kierunki wektorów (w niniejszym tomie). 
nach Zjednoczonych ${ }^{16}$. Praktyka amerykańska wskazuje jednak, że nadal aktualny pozostaje problem rozróżnienia immunitetu państwa i immunitetu personalnego najwyższych urzędników. Warto zauważyć w tym kontekście istotny wpływ, jaki na orzecznictwo sądów amerykańskich wywierają stanowiska prezentowane przez rząd amerykański w kwestii istnienia i zakresu immunitetów przysługujących najwyższym przedstawicielom państw obcych.

Problemy dotyczące stosowania immunitetów personalnych najwyższych urzędników państwa pojawiły się w ostatnim czasie również w praktyce międzynarodowej. Wiążą się one przede wszystkim z uznaniem istnienia czynów zakazanych przez prawo międzynarodowe - przestępstw międzynarodowych oraz w konsekwencji z działalnością trybunałów ad hoc do spraw byłej Jugosławii i Rwandy, utworzeniem Międzynarodowego Trybunału Karnego, a także szeregiem postępowań przeciwko głowom państw i innym osobistościom toczących się przed sądami krajowymi (m.in. sprawą Pinocheta przed angielską Izbą Lordów). Podstawowy problem stanowi odpowiedź na pytanie, czy w sytuacji, gdy odpowiedzialność karna jednostek za zbrodnie przeciwko prawu międzynarodowemu nie budzi wątpliwości, możliwe jest utrzymanie ochrony najwyższych urzędników państwowych przez przyznanie im immunitetu. Zagadnienie to stało się przedmiotem rozstrzygnięć zarówno $\mathrm{MTS}^{17}$, jak i międzynarodowych trybunałów karnych ${ }^{18}$. Międzynarodowy Trybunał Sprawiedliwości wydaje się chronić interesy państw przez restrykcyjne podejście do wyłączenia immunitetu ich najwyższych funkcjonariuszy. Jednocześnie jednak dostrzega, że w przypadku międzynarodowych trybunałów karnych kwestia immunitetu została uregulowana $\mathrm{w}$ ich statutach, które jednak ustanawiają reżim specjalny i nie mogą być uznawane za przejaw tworzenia się norm powszechnego prawa międzynarodowego (w konsekwencji MTS uznaje te postanowienia $\mathrm{z}$ irrelewantne). W istocie postanowienia dotyczące wyłączenia immunitetów mogą być interpretowane jako zrzeczenie się przez państwa-strony immunitetu w zakresie objętym jurysdykcją trybunałów karnych.

Ograniczenia immunitetów mających swoje źródło w prawie międzynarodowym wynikają z ewolucji prawa międzynarodowego. Wydaje się jednak, że teza o erozji suwerenności państw, a co za tym idzie ochrony gwarantowanej przez prawo międzynarodowe w postaci immunitetów, jest nieuzasadniona. Ostrożność, z jaką podchodzą do ograniczeń immunitetów sądy międzynarodowe, w szczególności MTS, dowodzi, że podstawowa zasada, na której opiera się prawo

16 J. Skrzydło, Immunitet państwa a immunitet przedstawiciela państwa w orzecznictwie Sadu Najwyższego Stanów Zjednoczonych (w niniejszym tomie).

${ }_{17}$ W. Czapliński, Immunitet wysokich funkcjonariuszy państwa w orzecznictwie MTS (w niniejszym tomie); T. Ostropolski, Immunitet personalny najwyższych funkcjonariuszy państwa - problemy najnowszej praktyki (w niniejszym tomie).

${ }^{18} \mathrm{~K}$. Wierczyńska, Immunitet urzędującej głowy państwa przed Międzynarodowym Trybunatem Karnym - uwagi na marginesie sprawy Omara Bashira (w niniejszym tomie). 
międzynarodowe - zasada równej suwerenności państw - pozostaje niezmieniona. Jej ograniczenia są dopuszczalne w zakresie koniecznym dla ochrony podstawowych wartości, na których opiera się prawo międzynarodowe, nie mogą jednak prowadzić do naruszenia jej istoty.

Opracowanie obejmuje stan prawny na dzień 30 marca 2011 r. 